International Research Journal of Public and Environmental Health Vol.8 (5),pp. 276-283, September 2021

Available online at https://www.journalissues.org/IRJPEH/

https://doi.org/10.15739/irjpeh.21.029

Copyright (C) 2021 Author(s) retain the copyright of this article

ISSN 2360-8803

CrossMark

\&lick for updates

Original Research Article

\title{
Bovine brucellosis seroprevalence and potential transmission risk to workers at the Port-Bouët abattoir, Abidjan, Côte d'Ivoire
}

\section{Kaba Soufiana1, Acapovi-Yao Genevieve Lydie1, Dagnogo Komissiri ${ }^{2}$, Kallo Vessaly ${ }^{3}$, Sevidzem Silas Lendzele ${ }^{4 *}$ and SergeBakou $^{5}$}

1UFR Biosciences, Université Félix Houphouët-Boigny, Abidjan, Côte d'Ivoire

${ }^{2}$ District Autonome d'Abidjan, Abattoir et de l'hygiène alimentaire de Port-Bouët, Côte d'Ivoire

${ }^{3}$ Direction des Services Vétérinaires (DSV), Abidjan, Côte d'Ivoire ${ }^{4}$ Laboratoire d'Ecologie Vectorielle (LEV), Department of Animal Biology, Institute of Research in Tropical

Ecology, Libreville, Gabon

${ }^{5}$ UFR Sciences de la Nature, Université Nangui Abrogoua, Abidjan, Côte d'Ivoire

*Corresponding Author Email: sevidzem.lendze@gmail.com

Tel : +241065417877
Brucellosis is one of the most common bacterial zoonosis globally and is caused by Brucella species. This disease remains one of the neglected diseases, most especially in the developing countries where it represents a public health threat. A cross sectional study was conducted at the Port-Bouët abattoir to determine the seroprevalence and associated transmission risk factors. Three hundred and eighty-seven (387) cattle blood samples collected from January 5 to March 302019 were diagnosed using the Rose Bengal and indirect Enzyme-linked Immunosorbent Assay (i-ELISA) techniques. Data was analyed using the JASP statistical software. The seroprevalence was $0.52 \%(95 \%$ CI: 0.06265-1.8542) for i-ELISA and Rose Bengal. The seroprevalence of bovine brucellosis in the male and female cattle tested were $0.3 \%$ (95 CI: $0.00776-1.6617)$ and $1.85 \%$ (95\% CI: $0.04687-9.8991)$ respectively for both the Rose Bengal and i-ELISA tests with no statistically significant difference $\left(X^{2}=2 ; d f=1 ; p=0.157\right)$. Animals >3years old had higher seroprevalence rate eventhough not statistically significant $\left(X^{2}=3 ; \mathrm{df}=2\right.$; $p=0.223$ ). From the responses of abattoir workers, the regular exposure to slaughtered animals, poor personal hygiene and the negligence of use of personal protective materials were the main possible sources for the transmission of this zoonosis in the abattoir.This study provides baseline information to guide abattoir authorities in Abidjan to design strict biosecurity measures to mitigate the spread of brucellosis to abattoir workers.

Keywords: Bovine brucellosis, risk factors, transmission, workers, Port-Bouët abattoir.

\section{INTRODUCTION}

Brucellosis is an infectious and contagious zoonotic disease with common clinical manifestation being abortion in animals (Khan and Zahoor, 2018). Thus, in domestic animals, it causes very significant economic losses (Godfroid et al., 2004). Brucellosis is an important and notifiable disease in the animal health sector due to the significant public health threat (Mustafa and Nicoletti, 1995). This disease is caused by various facultative, gramnegative intracellular bacteria belonging to the genus Brucella which usually infect some animal species. However, most species of the genus Brucella are also capable of infecting other animal species. The disease affect 
cattle, suidae, sheep, goats, horses, camels and dogs. It can also affect other ruminants, some marine mammals and even humans. The main species are Brucella melitensis (sheep, goats), Brucella abortus (bovids (ubiquitous) and Brucella suis (suidae). Transmission can be horizontal (via aborted fetuses, slaughter of infected animals, ingestion of milk or contaminated meat and airborne) or vertical i.e. from mother to newborn (in utero, or during the passage of the newborn through the pelvic route). Human contamination can occur either through the cutaneousmucous route (infection through wounds on the hands, in the oral or nasal mucosa, through contaminated hands) or through food (meat, milk and derivatives and vegetables). Milkers and animal owners are the most exposed groups to brucellosis. Likewise, veterinarians and para-veterinarians, abattoir workers, raw animal products consumers (milk and meat) are at high risk of exposure (Mburu et al., 2021). In Côte d'Ivoire, outbreaks of bovine brucellosis have been identified mainly in the northern part of the country, with infection rates ranging from 12 to 14\% (Angba et al., 1987). Further, a bayesian analysis conducted using serological data reported brucellosis prevalence rate of $8.8 \%$ in central Côte d'Ivoire (Sanogo et al., 2008). The main neighbouring countries supplying cattle to the Abidjan cattle market are Burkina Faso and Mali. These are two Sahelian countries that share borders with Côte d'Ivoire. Surveys conducted on brucellosis in these two border countries revealed the presence of brucellosis. Thus, in Mali, the report of Tounkara et al., (1994), Maiga et al., (1995) and Sow (2011) presented prevalences of $22 \%, 19.7 \%$ and $1.5 \%$ respectively. In Burkina Faso, the investigations conducted on this disease by Akakpo (1987), Traoré et al. (2004) and Boussini et al. (2012) revealed prevalence rates of $14.3 \%$, $8 \%$ and $3.61 \%$ respectively.

Based on these observations, the following scientific research questions were stated for this study: (1) what is the impact of transboundary livestock trade on the prevalence of bovine brucellosis at the Port Bouët abattoir? (2) what factors could be associated with the risk of abattior workers contracting brucellosis? Also, the paucity of data on the prevalence of brucellosis at the abattoir-level in Côte d'Ivoire which represents a critical point for the exposure and transmission of the disease to abattoir workers prompted this present study.

\section{MATERIALS AND METHODS}

\section{Study area}

The present study was conducted at the Port-Bouët abattoir, located in the municipality of Port-bouët in the southern part of the city of Abidjan, between the Atlantic Ocean to the south and the Ebrié lagoon in the North (YaoAcapovi et al., 2018). This municipality covers an area of $111.1 \mathrm{~km}^{2}$. The climate of this area is sub-equatorial, hot and humid, characterized by two rainy seasons (from September to October and from April to July) interspersed by two dry seasons (from July to August then from November to March). The average temperature fluctuates between 25 and $33{ }^{\circ} \mathrm{C}$ with a heavy rainfall of more than 1,500 mm per year (Yao-Acapovi et al., 2018). The Abidjan cattle market that supplies cattle to the abattoir covers an area of 3.2 hectares and is the largest in the country (YaoAcapovi et al., 2018). The share of the Abidjan cattle market in the national imports is $77 \%$ for cattle and $60 \%$ for small ruminants (Yao and Kallo, 2015). The small ruminant (sheep and goats) section of the market has 600 pens and an abattoir covering an area of 1.8 hectares.

\section{Sample size determination and blood collection}

A sampling frame was constructed to list all the registered cattle at the abattoir in collaboration with the technical staff. The total number of cattle to be sampled was calculated by assuming that the prevalence of the disease at the abattoir is $5 \%$ (estimated prevalence from past studies) at $95 \%$ confidence interval (CI) with $5 \%$ desired precision by using the following formu:

$$
\mathrm{N}=\frac{1.96^{2} \mathrm{P}_{\exp }\left(1-\mathrm{P}_{\exp }\right)}{\mathrm{d}^{2}}
$$

Where

$\mathrm{N}$ = sample size,

Pexp $=$ expected prevalence, and

$\mathrm{d}=$ absolute precision (Thrusfield, 2007).

From the above formula, the estimated sample number was 384, but sampling was conducted on 387 cattle. $4 \mathrm{ml}$ of blood was collected from slaughtered cattle into anticoagulant free tubes (Chantal and Thomas, 1976). These tubes were immediately placed in a cooler and sent to the Bingerville Central Veterinary Laboratory (LCVB) where the sera were prepared and stored frozen $\left(-20{ }^{\circ} \mathrm{C}\right)$ prior to serological analyzes.

\section{Questionnaire study on abattoir workers on Brucellosis}

A descriptive cross-sectional study with simple random sampling made it possible to interview 100 individuals at the Port-Bouët abattoir. This method consisted of randomly selecting workers from all available workstations of the abattoir. In addition, the survey sheet was designed using the Sphinx software. The questionnaire focused on assessing the general principles of hygiene, the experience of workers, time of contact with animals or blood, the use of PPEs and the consumption of milk from animals.

\section{Laboratory tests}

Two serological tests were used in this study- the Rose Bengal (RB) and the indirect Enzyme Linked Immunosorbent Assay (i-ELISA) tests. All samples were double-tested (RB and i-ELISA). The Rose Bengal and the ELISA kits were manufactured by ID.VET Innovative Diagnostics, France. The RB test principle is based on rapid 
Table 1. Prevalence of brucellosis with breed, sex and age cohort of cattle

\begin{tabular}{|c|c|c|c|c|c|c|c|}
\hline Parameters & Category & N(\%) & RB-test & i-ELISA & $X^{2}$ & df & P-value \\
\hline \multirow[t]{2}{*}{ Breed } & Zebu & $362(95.54)$ & $2(0.52)$ & $2(0.52)$ & 2.000 & 1 & 0.157 \\
\hline & Taurine & $25(6.46)$ & $0(0)$ & $0(0)$ & & & \\
\hline \multirow[t]{3}{*}{ Age (years) } & $<3$ & 5 (1.29) & $0(0)$ & $0(0)$ & 3.000 & 2 & 0.223 \\
\hline & $\geq 3 \leq 6$ & $195(50.39)$ & $2(0.52)$ & $2(0.52)$ & & & \\
\hline & $>6$ & $187(48.32)$ & $0(0)$ & $0(0)$ & & & \\
\hline \multirow[t]{2}{*}{ Sex } & Female & 54 (13.95) & $1(1.85)$ & $1(1.85)$ & 2.000 & 1 & 0.157 \\
\hline & Male & $333(86.05)$ & $1(0.3)$ & $1(0.3)$ & & & \\
\hline
\end{tabular}

Ab-Ag agglutination. It detects IgG antibodies (OIE, 2016). On the other hand, the i-ELISA test, is a semi-quantitative antibody detection method that works with the same principle of agglutination as the RB.

\section{The buffered antigen test or rose bengal test}

The test serum $(0.03 \mathrm{ml})$ was mixed with an equal volume of RBT antigen on a glass slide to produce a zone of approximately $2 \mathrm{~cm}$ in diameter. The mixture was agitated gently for 4 min at ambient temperature and then observed for agglutination. Tests were considered positive when any visible reaction or agglutination were observed.

\section{The indirect ELISA test}

The "ID Screen ${ }^{\circledR}$ Brucellosis Serum Indirect Multispecies" iELISA kit (ID vet France, kit reference BRUS-MS-5P) was used to test sera. All the testing procedures were performed according to the protocols provided by the manufacturer. The test plates were read under the ELISA reader ("Multiskan ${ }^{\mathrm{TM}}$ FC Microplate Photometer") at an optical density (OD) of $450 \mathrm{~nm}$ within $15 \mathrm{~min}$.

\section{Data processing and statistical analysis}

The data collected was entered in the Excel spreadsheet version 2013. The same spreadsheet was used to calculate the prevalence using the following formula:

Apparent prevalence $=($ Number of positive animals / Number of animals sampled) $\times 100$

Animals that tested positive for one of the two diagnostic tests were considered seropositive.

Statistical analysis was conducted using the JASP 0.13.0.0 statistical software package (JASP Team, 2020). The Chisquare test was used to compare the apparent prevalence of the study variables (sex, age and origin of the animals). The significant level of the test was stated at $p<0.05$.

\section{Ethical considerations}

The study was conducted under the strict supervision and agreement of the Directorate of Veterinary Services (DSV), the Directorate of the abattoir and Hygiene of the District of Abidjan. In addition, prior consent was obtained from anyone agreeing to be interviewed (verbal informed consent). They were told they could withdraw from the study at any time. The handling of animals and samples was carried out in accordance with the standards and respect of animal welfare (Australian Code for the Responsible Conduct of Research).

\section{RESULTS}

\section{Bovine brucellosis seroprevalence}

Out of the 387 cattle samples tested for brucellosis, only two (2) (0.52\% (95\% CI: 0.06265-1.8542)) tested positive with the Rose Bengal test and i-ELISA. These positive samples were from Zebu originating from Mali. Regarding the anti-Brucella antibodies prevalence with breed of cattle, it was found that the zebu had more of such antibodies than their taurine counterparts though no statistically significant difference $\left(X^{2}=2 ; \mathrm{df}=1 ; \mathrm{p}=0.157\right)$. Animals above three (3) years old (0.54\%: 95 CI: 0.06535-1.93369) had high levels of anti-Brucella antibodies than those below three (3) years old $(0 \%) \quad\left(X^{2}=3 ; \mathrm{df}=2 ; \mathrm{p}=0.223\right)$ (Table 1).The anti-Brucella antibody prevalence rate was higher in females (1.85\% (95\% CI: 0.04687-9.8991)) than the male (0.3\% (95\% CI: 0.00776-1.6617)) $\left(X^{2}=2 ; \mathrm{df}=1 ; \mathrm{p}=0.157\right)$.

\section{Origin of animals slaughtered at the abattoir}

Most of the animals slaughtered at the Port-Bouët abattoir originated from Mali (189 (49\%)), followed by Burkina Faso (166 (43\%)), then Côte d'Ivoire (29 (7\%)) and lastly from Niger $(3(1 \%))$. It was noticed that the two positive cases for brucellossis at the abattoir were diagnosed in cattle from Mali.

\section{Findings of the questionnaire study on brucellosis among abattoir workers}

\section{Sex of respondents}

Ninety-seven (97\%) of the population surveyed were men while only $3 \%$ consisted of women (Table 2 ).

\section{Task of respondents}

The respondents worked at various posts of the abattoir. 
Table 2. Findings from questionnaire study on brucellosis among abattoir workers

\begin{tabular}{|c|c|c|c|c|c|c|}
\hline Parameters & Category & Number & $\%$ & $\mathbf{X}^{2}$ & df & P-value \\
\hline \multirow[t]{2}{*}{ Sex } & Male & 97 & 97 & 2.000 & 1 & 0.157 \\
\hline & Female & 3 & 3 & & & \\
\hline \multirow[t]{5}{*}{ Professional experience (years) } & $>1$ & 3 & 3 & 20.000 & 16 & 0.220 \\
\hline & $1-5$ & 22 & 22 & & & \\
\hline & $5-10$ & 31 & 31 & & & \\
\hline & $10-20$ & 27 & 27 & & & \\
\hline & $>20$ & 17 & 17 & & & \\
\hline \multirow[t]{2}{*}{ Number of tasks conducted } & 1 & 83 & 83 & 2.000 & 1 & 0.157 \\
\hline & $>1$ & 17 & 17 & & & \\
\hline \multirow{9}{*}{$\begin{array}{l}\text { Type of activity conducted at } \\
\text { the abattoir }\end{array}$} & Butchers & 15 & 18.07 & 54.000 & 48 & 0.256 \\
\hline & Animal transporters & 10 & 12.05 & & & \\
\hline & Livestock traders & 9 & 10.85 & & & \\
\hline & Cleaners & 7 & 8.43 & & & \\
\hline & Inspectors & 7 & 8.43 & & & \\
\hline & Slaughterers & 8 & 9.64 & & & \\
\hline & Livestock trader assists & 8 & 9.64 & & & \\
\hline & Meat vendors & 6 & 7.23 & & & \\
\hline & Others & 13 & 15.66 & & & \\
\hline \multirow[t]{2}{*}{ Contact with live animals } & contact & 59 & 59 & 2.000 & 1 & 0.157 \\
\hline & No contact & 41 & 41 & & & \\
\hline \multirow[t]{2}{*}{ Contact with carcass } & contact & 53 & 53 & 2.000 & 1 & 0.157 \\
\hline & No contact & 47 & 47 & & & \\
\hline \multirow[t]{2}{*}{ Contact with blood } & contact & 60 & 60 & 2.000 & 1 & 0.157 \\
\hline & No contact & 40 & 40 & & & \\
\hline Duration of working time & $<2$ & 9 & 9 & 20.000 & 16 & 0.220 \\
\hline \multirow[t]{4}{*}{ (hours/day) } & $2-6$ & 8 & 8 & & & \\
\hline & $6-10$ & 15 & 15 & & & \\
\hline & $10-12$ & 10 & 10 & & & \\
\hline & $>12$ & 59 & 59 & & & \\
\hline \multirow[t]{2}{*}{ Eating on duty } & With working attire & 72 & 72 & 2.000 & 1 & 0.157 \\
\hline & Not with working attire & 28 & 28 & & & \\
\hline \multirow{4}{*}{$\begin{array}{l}\text { Frequency of washing of } \\
\text { working attires }\end{array}$} & 1 time/day & 58 & 58 & 12.000 & 9 & 0.213 \\
\hline & 1 time/2days & 30 & 30 & & & \\
\hline & 1 time/week & 8 & 8 & & & \\
\hline & 2 times/week & 4 & 4 & & & \\
\hline \multirow[t]{2}{*}{ Working gloves } & Absence & 29 & 29 & 2.000 & 1 & 0.157 \\
\hline & Presence & 71 & 71 & & & \\
\hline \multirow[t]{2}{*}{ Washing of hands before meal } & Water and soap & 86 & 86 & 2.000 & 1 & 0.157 \\
\hline & Water only & 14 & 14 & & & \\
\hline \multirow[t]{2}{*}{ Working with open sores } & Yes & 75 & 75 & 2.000 & 1 & 0.157 \\
\hline & No & 25 & 25 & & & \\
\hline \multirow{2}{*}{$\begin{array}{l}\text { Consumption of the milk of } \\
\text { animals of the abattoir }\end{array}$} & Yes & 61 & 61 & 2.000 & 1 & 0.157 \\
\hline & No & 39 & 39 & & & \\
\hline \multirow[t]{3}{*}{ Nature of the milk consumed } & Raw & 16 & 26.23 & 6.000 & 4 & 0.199 \\
\hline & Boiled & 23 & 37.70 & & & \\
\hline & Raw and boiled & 22 & 36.07 & & & \\
\hline \multirow[t]{2}{*}{ Use of PPEs } & Yes & 83 & 83 & 2.000 & 1 & 0.157 \\
\hline & No & 17 & 17 & & & \\
\hline
\end{tabular}

Thus, $17 \%$ of them worked in more than two posts while $83 \%$ worked in only one post. Among the $83 \%$ surveyed working in atleast one post, $15 \%$ consisted of butchers, $10 \%$ animal transporters, $9 \%$ cattle dealers, $8 \%$ slaughterers, $8 \%$ cattle dealer assists, $7 \%$ cleaners, $7 \%$ inspectors. Finally, 6\% of our interviewees were working in one section while $13 \%$ worked in multiple sections. Of the $13 \%$ respondents working in different sections of the abattoir, $30.8 \%$ consisted of meat roasters, $15.4 \%$ retailers,
7.7\% skin burners, $15.4 \%$ were agents of the Abattoir Department of Food Hygiene (DAHA), 23\% consisted of sellers of roasted meat "Choukouya" and 7.8\% sellers of skin (Table 2).

\section{Working experience at the abattoir}

Regarding the professional experience of the respondents, $31 \%$ had between 5 and 10 years of experience, $27 \%$ 
claimed to have worked between 10 and 20 years, $22 \%$ had between 1 and 5 years while $17 \%$ said they have been in the office for more than 20 years. Only 3\% of respondents have been at the abattoir for less than 1 year (Table 2).

\section{Contact of workers with live animals, blood and carcass}

From our interview, we noticed that $59 \%$ of workers came in contact with live animals while $41 \%$ said the contrary. They claimed to be in contact with carcass (53\%) and $47 \%$ claimed not to have been in contact with carcass. $60 \%$ of workers were exposed to the blood of slaughtered animals compared to $40 \%$ that did not. Fifty-seven percent (58\%) of workers claimed to work more than 12 hours a day; $15 \%$ between 6 and 10 hours/day; 10\% between 10 and 12 hours/day; $8 \%$ between 2 and 6 hours/day and only $9 \%$ worked less than 2 hours/day (Table 2). The average working time at the abattoir was 13 hours/day.

\section{Some practices of abattoir workers}

Out of the 100 individuals surveyed, 72 (72\%) claimed to eat with their working attires while $28 \%$ said they changed their working clothings before eating. Regular washing of working attires is very crucial in implementing good hygienic practices. Indeed, of the 100 individuals interviewed, more than 58\% said they washed their working attires every day whereas $30 \%$ said they did it after every two days, $7 \%$ washed their outfits once a week and $4 \%$ cleaned it two times a week.

During working periods, 29\% of respondents responded positively to the wearing of gloves while $71 \%$ did not wear them. It was noticed that $86.5 \%$ of the target population washed their hands with soap and water before eating their meals whereas $13.5 \%$ washed their hands only with running water. The results of our survey confirmed that $75 \%$ of workers continue to work even with open wounds while $25 \%$ said that the presence of an open wound prohibited them from performing well. From the dietary exposure analysis, we found that $61 \%$ of respondents claimed to consume milk from their animals while $39 \%$ did not. Among those who consumed milk from their animals, $37.7 \%$ consumed boiled milk and $26.23 \%$ consumed raw milk and $36.07 \%$ consumed both raw and boiled milk.

\section{Workers' knowledge on the existence of zoonoses and PPEs}

The present survey revealed that $84 \%$ of our study population claimed to be aware of the existence of zoonotic diseases, but $16 \%$ did not know that such diseases exist. Of the 100 workers surveyed, only $83 \%$ found PPEs to be useful, while $17 \%$ said that wearing PPEs was not important in performing their tasks (Table 2).

\section{DISCUSSION}

Two serological diagnostic methods were used in this study to establish the existence of Brucella species infection. These methods were the RB and the i-ELISA tests. The results of our diagnostic tests revealed positivity concordances between the two serological tests. This observation is similar to that made by Koutinhouinet al., (2003). All the seropositive animals detected with the RB test were also positive with the i-ELISA test. However, this finding was different from that of Adamou (2014) in Niger, Sanogo (2008) in Côte d'Ivoire and Amona (2016) in the Republic of Congo who reported variable results between the RB and i-ELISA tests.

The apparent prevalence of bovine brucellosis in this study was $0.52 \%$. The low prevalence of bovine brucellosis reported in this study may be due to the duration of this study that was conducted within a short period (from 01 to 28 February 2019) and the method of cattle breeding (extensive breeding) (Mburu et al., 2021). Indeed, studies have shown that the method of animal breeding and the season have an impact on the prevalence of this disease because a hot and dry climate destroys Brucella (Mburu et al., 2021). Also, since in the extensive animal breeding system, animals are kept for longer periods in fresh pastures and in a humid environment, this could have an influence in the detection of the disease (Saegerman et al., 2010).

The apparent prevalence of bovine brucellosis obtained in this study was higher to what was reported by Kouamé et al. (2015) in abattoirs in Senegal but lower than 9.6\% at the Dschang abattoir in the west region of Cameroon (SheyNjila et al., 2005) and $8.7 \%-12 \%$ at the Dakar abattoir in Senegal (Chantal and Thomas, 1976). These results are significantly lower than those previously reported in farms throughout the Ivorian territory by Angba et al. (1987) and Pilo-Moron et al. (1979) whose prevalences were within the range of $12-14 \%$ and $10.8 \%$ respectively. The same is true for the results of the study carried out in the center of Côte d'Ivoire by Sanogo et al., (2008) where the prevalence obtained was $8.8 \%$ and in the north of Côte d'Ivoire by Kanouté et al. (2017) with prevalence rate of $4.6 \%$.

The apparent prevalence of this study is also lower than the prevalence from studies carried out in countries where animals originated from before reaching Côte d'Ivoire. Thus, in Mali, the survey of Tounkara et al. (1994), Maiga et al. (1995) and Sow (2011) indicated prevalences of $22 \%$, $19.7 \%$ and $0.98 \%$ respectively. The investigations carried out on this disease by Akakpo (1987), Traoré et al. (2004) and Boussini et al. (2012) revealed prevalences of 14.3\%; $8 \%$ and $3.61 \%$ respectively. These prevalences are higher than that obtained by Kouamé et al. (2015) in an abattoir in Senegal. These discrepancies in the prevalences of brucellosis in Côte d'Ivoire could be explained by the differences in sampling (size, procedure, etc), the type of animals, the epidemiological context, the tests used and the fact that the Ivorian live cattle market is mainly supplied by two Sahelian countries which have a common border with Côte d'Ivoire (Yao and Kallo, 2015).

The apparent prevalence of bovine brucellosis was higher in females $(1.85 \%)$ than in males $(0.3 \%)$. This finding is 
similar to reports from Chantal and Thomas (1976), Kubuaforet al. (2000), Traoré et al. (2004), Faye et al. (2005) and Amona (2016). This trend of seroprevalence with sex can be explained by the fact that females are often kept for longer periods for production activities such as milk, reproduction, etc, thus they are much more exposed to infections than their male counterparts (Mburu et al., 2021). Also, females that are taken to the abattoir usually reports fertility problems and suffer from infections. Elderly animals (> 3years) recorded a higher seroprevalence than their younger counterparts. An increase in seropositivity with age has already been demonstrated (Traoré et al., 2004; Faye et al., 2005; Chimana et al., 2010; Kubuaforet al., 2000). This observation could be justified by the fact that the number of younger animals (0 to 3 years) was lower. As a result, the likelihood of having many positive cases with the younger cohort was lower. In addition, adults often stay in the herd for a longer period which leads to their longer exposure to the risk of contamination and accumulation of antibodies over such a period. The trend seems logical because the older the animal, the more likely they are to be infected and become source of contamination for younger ones (Koutinhouin et al., 2003). Asmare et al. (2013) reported that brucellosis is primarily a disease of sexually matured animals and sensitivity to testing increases with sexual maturity and gestation due to the influence of sex hormones.

Based on the risk of exposure for abattoir workers to brucellosis, the transmission of brucellosis occurs through direct contact with a sick animal or its tissues, carcass, but also with contaminated environment (Dahouk et al., 2013). Among the abattoir workers interviewed, $59 \%$ were in contact with live animals, 53\% were in contact with carcases, $60 \%$ of workers were exposed to the blood of slaughtered animals, more than $40 \%$ of workers did not carry out daily washing of their working attires and 75\% worked with open sores. The contact time between abattoir workers and these dangerous contamination sources was very long (13h/day). This exposure of abattoir workers to blood, secretions and tissues for a long time theoretically increases the risk of exposure to infection. The risk of transmission of bovine brucellosis to humans exists although the prevalence of bovine brucellosis in this study is low $(0.52 \%)$. This could be explained by the very rudimentary slaughtering and waste treatment system (killings), the poor organization of work by workers of the abattoir and the non-compliance with hygiene measures.

Regarding the use of PPEs and the practices of abattoir workers, $72 \%$ said they ate with their working attires and $14 \%$ said they washed their hands only with running water without soap before eating. $71 \%$ of workers did not wear gloves, $17 \%$ said wearing PPEs during work was not important. Thus, observations regarding the use of PPEs by abattoir workers showed that none of them used protective clothing, but only the inspectors and butchers wore PPEs. This observation is similar to that made by several authors (Ayoola et al., 2017; Abadane, 2014; Swai and Schoonman,
2009), who reported that the risk of contracting brucellosis by abattoir workers was high due to their handling of tissues and live animals without using PPEs. The insufficient use of PPEs by these workers puts them at serious risk of contracting brucellosis and other zoonotic diseases in such an unsanitary and highly contaminated environment (Adeyemo, 2002; Adeyemo et al., 2002).

For the food exposure risk of abattoir workers, $61 \%$ of them claimed to consume milk from their animals. Of these, $37.7 \%$ consumed boiled milk, $26.23 \%$ consumed raw milk and $36.07 \%$ consumed both raw and boiled milk. Consumption of raw milk is an important factor for the transmission of brucellosis and other zoonoses (Mburu et al., 2021). Any sick animal is susceptible to transmitting a pathogen through milk or meat. In particular, animals suffering from tuberculosis or brucellosis shed infectious agents in milk such as Mycobacterium and Brucella respectively. The present observation is different from that of Sow (2011) in Mali who reported that $70.3 \%$ of the milk were consumed in raw and fermented forms, $20.8 \%$ in fermented form and $7 \%$ in raw form.

\section{Conclusion}

The objective of this work was to determine the prevalence of bovine brucellosis at the Port-Bouët abattoir through two serological tests (RB and i-ELISA).The results of the two serological tests showed that brucellosis is present with a low prevalence $(0.52 \%)$ in cattle of the abattoir. The practices and dietary exposure of abattoir workers could expose them to brucellosis. The lack of awareness among abattoir workers on the zoonotic implications of brucellosis is a key finding in this study. This study highlights the importance of improving hygienic conditions in abattoirs. Indeed, the presence of Brucella and poor hygiene practices could expose workers to brucellosis. It is therefore important to conduct an integrated study (humans and animals) which would enable the consistent evaluation of the risk and propose appropriate measures for the surveillance and control of bovine brucellosis at the abattoir level.

\section{Conflict of Interests}

The authors declare that there is no conflict of interests regarding the publication of this manuscript.

\section{REFERENCES}

Abadan Z (2014). Séroprévalence et facteurs de risque de la brucellose chez les professionnels des abattoirs de la région du grand Casablanca.Mémoire de fin d'études en cycle de spécialité en administration sanitaire et sante publique filière : épidémiologie de santé publique. Ecole Nationale de Santé Publique. Royaume du Maroc. 38p. Adamou HH (2014). Evaluation de trois tests de dépistage 
de la brucellose bovine pour une aide décisionnelle de contrôle de la maladie dans le bassin laitier de Niamey (NIGER). Mémoire de master en sante publique vétérinaire : épidémiologie des maladies transmissibles et gestion des risques sanitaires (EGRS): Dakar, $164 \mathrm{p}$.

Adeyemo KO (2002). Unhygienic Operation of a City Abattoir in South Western Nigeria: Environmental Implication. AJEAM/RAGEE., 4: 23-28.

Adeyemo OK, Ayodeji IO, Aiki-Raji CO (2002). The Water Quality and Sanitary Conditions in a Major Abattoir (Bodija) in Ibadan, Nigeria. Africa J. Biomed. Res., 5: 5155.

Akakpo AJ (1987). Brucellosesanimales en Afriquetropicale. Particularités épidémiologique, clinique et bactériologique. Rev. Elev. Méd. Vét. Pays Trop., 40 (4): 307- 320.

Amona I, Miassangoumouka JP, Banga-Mboko H, Adzona PP, Rabeson FA, Ikolakoumou J (2016). Dépistage sérologique de la brucellose bovine par l'épreuve àl'antigène tamponné (EAT) et l'ELISA dans un centre de multiplication et de métayage bovin en république du Congo-Brazzaville. J. Anim. Plant Sci., 27(3): 4315-4329.

Angba A, Traore A, Fritz P (1987). Situation de la brucellose animale en Côte-d'Ivoire. Rev. Elev. Méd. Vét. Pays Trop., 40 (4): 325-329.

Asmare K, Sibhat B, Mollac W, Ayeletd G, Shiferaw J, Martin AD, Skjerve E, Godfroid J (2013). The status of bovine brucellosis in Ethiopia with special emphasis on exotic and crossbred cattle in dairy and breeding farms. Acta Trop., 126 :186-192.

Ayoola MC, Akinseye VO, Eniola CE, Awosanya E, Popoola OA, Akinyemi OO, Lorraine PL, Taylor A, Judy SJ, Ignacio MI, Cadmus SI (2017). Prevalence of bovine brucellosis in slaughtered cattle and barriers to better protection of abattoir workers in Ibadan, South-Western Nigeria. Pan Afri. Med. J., 28: 68.

Boussini H, Traoré A, Tamboura HH, Bessin R, Boly H, Ouédraogo A (2012). Prévalence de la tuberculose et de la brucellose dans les élevages bovins laitiers intraurbains et périurbains de la ville d'Ouagadougou au Burkina Faso. Rev. Sci. Tech., 31(3): 943-951.

Chantal J, Thomas JF (1976). Etude sérologique sur la brucellose bovine aux abattoirs de Dakar. Rev. Elev. Méd. Vét. Pays Trop., 29: 101-108.

Chimana HM, Muma JB, Samui KL, Hangombe BM, Munyeme M, Matope G, Phiri AM, Godfroid J, Skjerve E, Tryland MA (2010). Comparative study of seroprevalence of brucellosis in commercial and small-scale mixed dairy beef cattle enterprises of Lusaka province and Chibombo district, Zambia. Trop. Anim. Hlth. Prod., 42:1541-1545.

Dahouk S, Sprague L, Neubauer H (2013). New developments in the diagnostic procedures for zoonotic brucellosis in humans. Rev. Sci. Tech., 32(1): 177-188.

Faye B, Castel V, Lesnoff M, Rutabinda D, Dhalwa J (2005). Tuberculosis and brucellosis prevalence survey on dairy cattle in Mbarara milk basin (Uganda). Prev. Vet. Med., 67: 267-281.

Godfroid J, Bishop GC, Bosman PP, Herr S (2004). Bovine brucellosis. In: Coetzer J.A.W., Tustin R.C., Eds., Infectious diseases of livestock. Cape Town, South Africa, Oxford University Press, 1510-1527.

JASP Team. (2020). JASP (Version 0.14.1) [Computer software]. https://jasp-stats.org.

Kanouté YB, Gragnon BG, Schindler C, Bonfoh B, Schelling E (2017). Reprint of "Epidemiology of brucellosis, Q Fever and Rift Valley Fever at the human and livestock interface in northern Côte d'Ivoire». Acta Trop.,165: 66-75.

Khan MZ, Zahoor M (2018). An Overview of Brucellosis in Cattle and Humans, and its Serological and Molecular Diagnosis in Control Strategies. Trop. Med. Infect. Dis., 3(2): 65.

Kouamé KGG, Kone PS, Sabi SS, Dahourou LD, Tialla D, Bonfoh B, Bakou SN, Akakpo AJ (2015). Brucellose bovine dans les élevages et abattoirs du Sénégal. Rev. Afri. Santé Prod. Anim.,13 (1-2): 33-37.

Koutinhouin B, Youssao AKI, Houehou AE, Agbadje PM (2003). Prévalence de la brucellose bovine dans les élevages traditionnels encadrés par le Projet pour le Développement de l'Elevage (PDE) au Bénin. Rev. Méd. Vét., 154(4): 271-276.

Kubafor DK, Awumbila B, Akanmori BD. 2000. Seroprevalence of brucellosis in cattle and humans in the Akwapim-South district of Ghana: public health implications. Acta Trop., 76: 45-48.

Maiga STMD, Niang M, Touré I (1995). Enquête séroépidémiologique sur la brucellose bovine dans la ceinture laitière de Bamako, Mali. In: Zessin, K.H. (Ed.), Livestock production and diseases in the tropics, livestock production and human welfare. Proceedings of the 8th International Conference of Institutions of Tropical Veterinary Medicine, Berlin, 25-29 September. 289-292.

Mburu CM, Bukachi SA, Tokpa HK, Fokou G, Shilabukha K, Ezekiel M (2021). Lay attitudes and misconceptions and their implications for the control of brucellosis in an agro-pastoral community in Kilombero district, Tanzania. PLoS Negl. Trop. Dis., 15(6): e0009500.

Mustafa AA, Nicoletti P (1995). FAO, WHO, OIE guidelines for a regional brucellosis control programme for the Middle $\quad$ East. http:// www.fao.org/ag/AGA/AGAH/ID/GUIDE-EN.htm.

OIE - World Organization for Animal Health (2009). Bovine brucellosis: manual of diagnos- tic tests and vaccines for terrestrial animals [Consulté le 01/02/2019]: http://www.oie.int/fileadmin/home/eng/health_standar ds/tahm/2.04.03_bovine_brucell.pdf.

OIE - World Organization for Animal Health (2016). "Brucellosis (Brucella abortus, B. melitensis and B. suis) (Infection with B. abortus, B. melitensis and B. suis)." Manual of Diagnostic Tests and Vaccines for TerrestrialAnimals, from [Consulted on the 01/02/2019]: http://www.oie.int/fileadmin/Home/fr/Health_standard s/tahm/ 3.01.04_brucellosis.pdf.

Pilo-Moron E, Pierre F, Kouame JB (1979). La brucellose bovine en Côte d'Ivoire. Epidémiologie. Rev. Elev. Méd. Vét. Pays Trop., 32 (4): 325-33.

Saegerman C, Berkvens D, Godfroid J, Walravens K (2010). 
Bovine brucellosis. In : Lefèvre P.C., Blancou J., Chermette R., Uilenberg G. (Eds), Infectious and parasitic diseases of livestock. Editions Médicale Internationales: Paris, 9711001.

Sanogo M, Cisse B, Ouattara M, Walvarens K, Praet N, Berkvens D, Thys E (2008). Real prevalence of bovine brucellosis in the center of Ivory Coast. Rev. Elev. Méd. Vét. Pays Trop., 61: 147-151.

Shey-Njila O, Daouda M, Nya E, Zoli PA, Walravens K, Godfroid J, Geerts S (2005). Enquête sérologique de la brucellose bovine au Cameroun. Rev. Elev. Méd. Vét. Pays Trop., 1951-6711.

Sow IM (2011). Évaluation du risque de la brucellose lié à la consommation du lait frais dans la commune rurale de Cinzana. Mémoire pour l'obtention du DEA en sciences biologiques appliquées, option microbiologie appliquée, faculté des sciences et techniques, université de Bamako (Mali), 64p.

Swai ES, Schoonman L (2009). Human Brucellosis: seroprevalence and risk factors related to highrisk occupational groups in Tanga Municipality, Tanzania. Zoonoses Pub. Hlth., 56(4): 183-187.
Thrusfiled M (2007). Veterinary Epidmiology; describing disease Ocurrence. Third. Hoboken: Blackwell Publishing Ltd.

Tounkara K, Maiga S, Traoré A, Seck BM, Akakpo J (1994). Epidémiologie de la brucellose bovine au Mali : enquête sérologique et isolement des premières souches de Brucella abortus. Rev. Sci. Tech., 13: 777-786.

Traoré A, Hamidou HT, Balé B, David WR, Nongasida Y, Moumouni S (2004). Prévalence globale des pathologies majeures liées à la production laitière bovine en système d'élevage intraurbain à Hamdallaye (Ouagadougou). Biotech. Agronom. Soc. Environ., 8: 3-8.

Yao BD, Kallo V (2015). Dynamique de l'approvisionnement du marché à bétail du district d'Abidjan. Rev. Géograph. Trop. Environ., 2: 86-96.

Yao-Acapovi GL, Mavoungou JF, Sevidzem SL (2018). Tick population on large and small ruminant species in the Port-Bouët cattle market in Abidjan, Ivory Coast. Livestock Res. Rural Development., 30 (6): 1-11. 